\title{
SRY wt Allele
}

National Cancer Institute

\section{Source}

National Cancer Institute. SRY wt Allele. NCI Thesaurus. Code C75528.

Human SRY wild-type allele is located in the vicinity of Yp11.3 and is approximately $1 \mathrm{~kb}$ in length. This allele, which encodes sex determining region Y protein, plays a fundamental role in testis formation in humans, and may also play a role in regulation of transcription. Mutations in this gene may result in gonadal dysgenesis. 